\title{
Cranial morphology of five felids: Acinonyx jubatus, Panthera onca, Panthera pardus, Puma concolor, Uncia uncia
}

\author{
Margaret E. Sims
}

\begin{abstract}
Felid skulls often appear as evidence in wildlife forensic casework at the National Fish and Wildlife Forensics Laboratory (NFWFL). Five species commonly seen in U.S.-imported trophy shipments include cheetah, jaguar, leopard, puma, and snow leopard. Because these species are given different levels of protection under federal, state, and international law, an effective prosecution requires species-level identification. There is limited comparative morphological information available to identify these skulls to species when country of origin is unknown. The purpose of the project was twofold: 1) to research speciesspecific characteristics that will differentiate five species of medium-sized felids based on skull morphology and 2) to develop identification aids to help wildlife law enforcement officers distinguish mid-size cat skulls. A visual comparison of qualitative non-metric features, such as the shape of the ectotympanic process and the expression of canine grooves, is sufficient to distinguish the five species. A flowchart and identification guide were developed to assist law enforcement officers in identifications when measuring devices cannot be used, especially when conducting undercover investigations.
\end{abstract}

KEY WORDS: cranial morphology, skull, Felidae, wildlife forensics.

Margaret E. Sims [cookie_smith@fws.gov], National Fish and Wildlife Forensics Laboratory, 1490 East Main Street, Ashland, OR 97520. USA.

\section{Морфология черепа пяти видов кошачьих: Acinonyx jubatus, Panthera onca, Panthera pardus, Puma concolor, Uncia uncia}

\author{
M.E. Симс
}

РЕЗЮМЕ. В практике Национальной криминалистической лаборатории рыболовства и дикой природы (NFWFL) черепа кошачьих часто фигурируют в качестве улик в судебных делах по вопросам охраны природы. Пять видов, часто ввозимых в США в качестве трофеев, включают гепарда, ягуара, леопарда, пуму и снежного барса. Поскольку эти виды имеют различный охранный статус в федеральном законодательстве США, законодательстве отдельных штатов и в международном праве, для эффективного расследования необходима идентификация на уровне видов. Существующей сравнительно-морфологической информации недостаточно для отнесения таких черепов к конкретным видам в случаях, когда страна их происхождения неизвестна. Исследование имело две цели: 1) выявить видоспецифические признаки отличия пяти видов среднеразмерных кошек по морфологии черепа; 2) разработать критерии идентификации черепов среднеразмерных кошачьих для сотрудников правоохранительных органов, связанных с вопросами охраны природы. Визуальное сравнение качественных неметрических признаков, таких как форма эктотимпанального отростка и выраженность бороздок на клыках достаточно для диагностики изученных пяти видов. Для помощи сотрудникам правоохранительных органов были разработаны блок-схема и руководство по определению черепов для случаев, когда невозможно использовать измерительные приборы, особенно при проведении негласных расследований.

КЛЮЧЕВЫЕ СЛОВА: череп, морфология Felidae, природоохранная криминалистика.

\section{Introduction}

Comparative morphology of skulls is a classical approach to answering questions about the relationships among species, often for classification and taxonomic distinctions. As applied in this research, it is a technique to determine and describe structural differences for the purposes of species identification. Wildlife law enforcement cases involving cat skull identification prompted the question: when country of origin is unknown, how does one tell the difference among felid skulls of similar size, for example, a snow leopard skull and a leopard skull? Skulls of medium-sized felids overlap in size (Hunter, 2011), and can be difficult to separate osteologically when geographic origin is unknown. The main objectives of the study were to describe species-specific characters of skulls of five felids for use in identifying skulls in wildlife forensic casework, and to develop tools to allow field investigators to make preliminary identifications of felid 


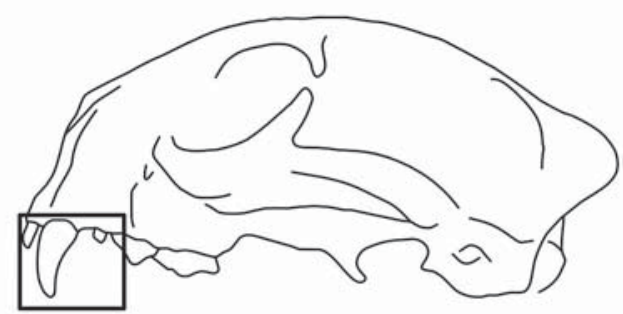

felid skull
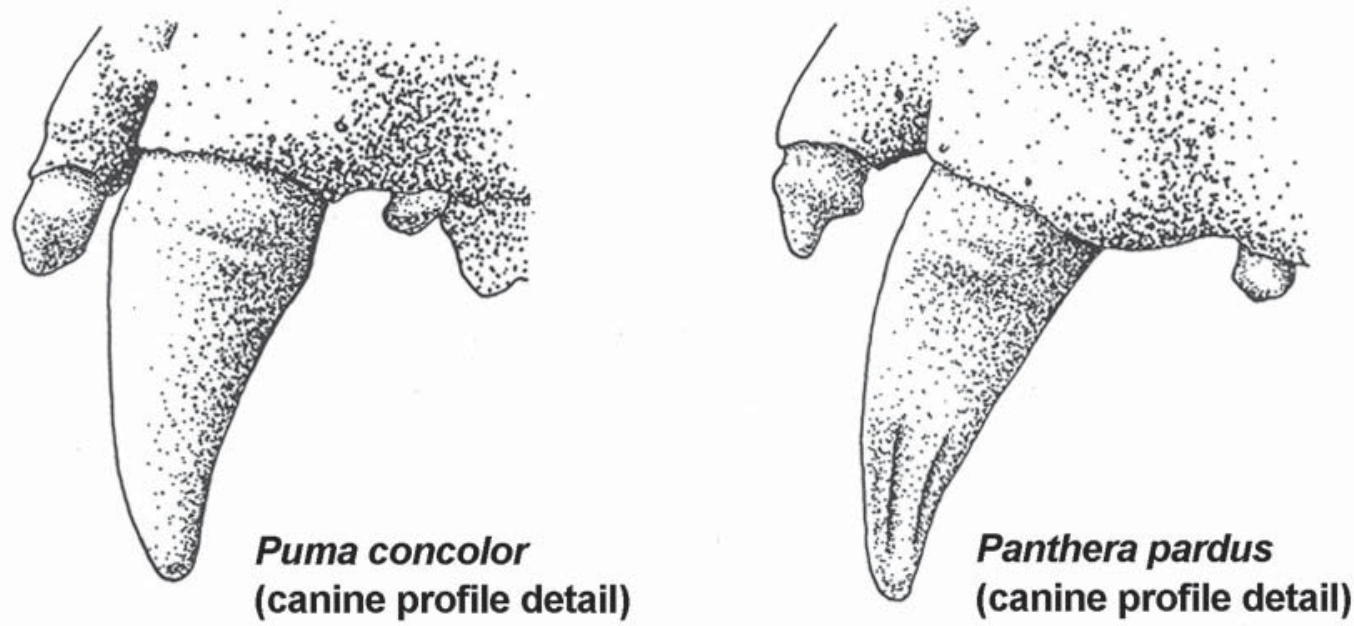

Figure 1. Canine profile detail, showing absence of pitted grooves in puma and presence of paired longitudinal pitted grooves in leopard.

skulls while processing shipments during import and export.

I separated the family Felidae into three general size categories: small, medium, and large. Small cats are most of the species within the subfamily Felinae including the small spotted cats and lynxes that generally weigh $<30 \mathrm{~kg}$. Medium cats are the five species included in this project: cheetah, jaguar, leopard, puma, and snow leopard. Clouded leopard (Neofelis nebulosa) and the largest lynx, Eurasian lynx (Lynx lynx), were excluded from the medium-sized cat group because skulls of these species are relatively much smaller and are rarely found in wildlife trade. Large cats are the two largest pantherines: lion and tiger.

Literature on comparative skull morphology of geographically-separated species is limited, most likely because country of origin information (combined with size) is often the leading factor when species identification is questioned. Recent zoologists may not be familiar with the contributions to felid morphology in zooarchaeological and paleontological literature, which describe multiple distinctive cranial characters (Merriam \& Stock, 1932; Schmid, 1940; Seymour, 1993). Comparative cranial morphology, dental characters, and morphometry of dental ratios are included in the German language monograph by E. Schmid (1940) "Varia- tionsstatisische Untersuchungen am Gebis pleistozaner und rezenter Leoparden und anderer Feliden." Articles on the taxonomy and systematics (phylogenetic relationship) of felids contain some information on comparative skull morphology (Werdelin, 1985; GarciaPerea, 1994). Angela von den Driesch (1976) designed and described standard cranial measurements for felids. Seymour (1999) compares cranial morphology of the small South American cats; and includes applicable characters that were investigated in this study. Cranial morphology of small wild cats has been described (Lekagul \& McNeely, 1988; de Oliveira 1998a, b; GarciaPerea, 2002), as have the cranial morphology of North American felids (Currier, 1983; Tumlison, 1987; Seymour, 1989; Lariviere \&Walton, 1997; Murray \& Gardner, 1997; de Oliveira, 1998a, b) and the mid-sized and larger cats of the genus Panthera (Todd, 1966; Werdelin, 1983; Lamerichs, 1985; Seymour, 1989; Larsen, 1997).

\section{Materials and methods}

I examined 61 adult skulls from different collections: cheetah Acinonyx jubatus $(n=11)$, jaguar Panthera onca $(n=12)$, leopard Panthera pardus $(n=14)$, puma Puma concolor $(n=13)$, and snow leopard Uncia 

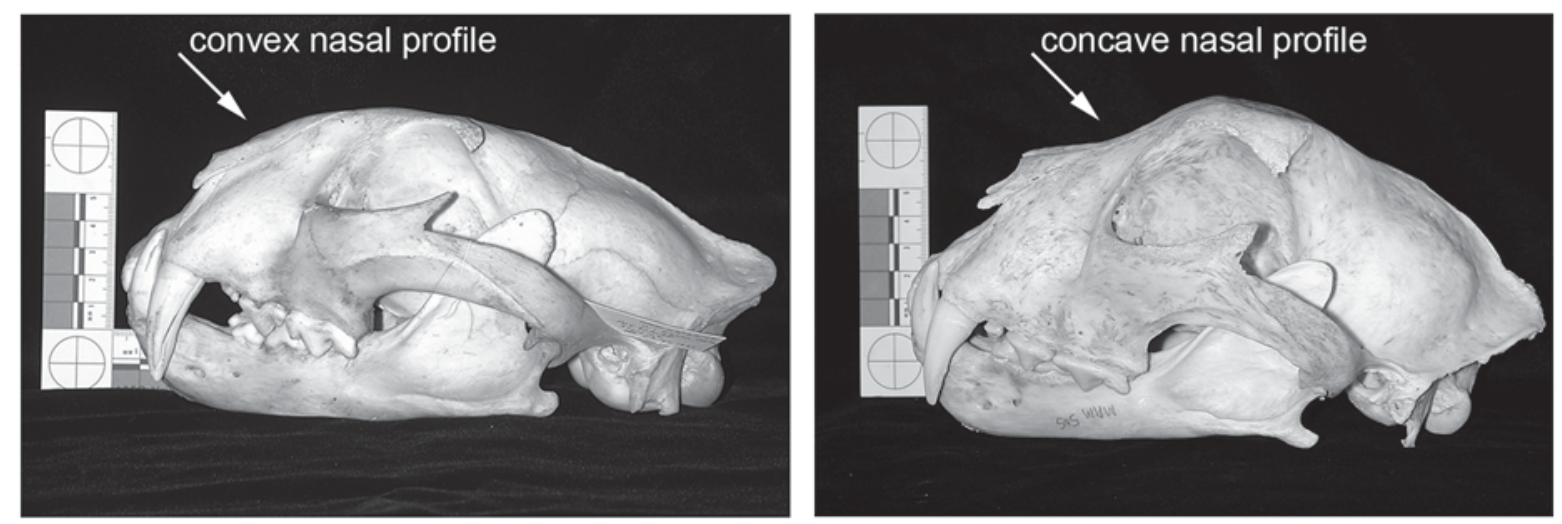

Figure 2. Comparison of convex and concave nasal profiles.

uncia $(n=11)$. No distinction was made between male and female specimens in order to increase sample size and prioritize skulls with minimal damage and dental completeness.

Canine grooves. Pitted canine grooves (Fig. 1) are a feature not unique to felids, but are important in describing felid canine structure (e.g., Nelson \& Goldman, 1933; Young \& Goldman, 1946; Lamerichs, 1985). Occurring prominently in smaller felid species also, paired grooves have been described as a lingual or labial ridge (Salles, 1992). Although the exact function of these grooves is questioned (possibly serving to drain blood during biting), this feature can be present in varying degrees of development and is absent or faint in some species. The grooves appear longitudinally (vertically) along the labial and lingual sides of the canines. When fully developed, they are paired elongated parallel grooves on both sides of each canine tooth. Using low-power magnification, small round pits are observed along the groove. The number of grooves and their prominence on canines is species-specific for the five cats studied here. As mentioned earlier, some specimens can have vertical cracks on the canine teeth, which appear much different and cannot be confused with a pitted groove. Cracks have sharp edges, expose the inner dentine layers of the tooth, and can extend to the tip of the tooth or beyond the cingulum, while grooves are pitted with rounded edges that do not penetrate the enamel surface and rarely reach the tip of the tooth or the cingulum.

Nasal profile. Nasal bones constitute the upper walls of the nasal cavity and lie just anterior to the frontal bone (forehead) and eye orbits. The nasal profile of felids has been previously described in Salles (1992) and Wilkins et al. (1997). The appearance of this feature affects the overall shape of the skull profile (as viewed from either lateral-most side), and differs among the species studied. The nasals can be described as convex or concave, with respect to the forward-projecting line of the frontal-nasal profile (Fig. 2).

Auditory region. The auditory bullae and associated characters have been described for several felids and appear different among species (Pocock, 1916; Merri- am \& Stock, 1932; Holliday, 2007). Because previous descriptions have focused on the internal morphology of the auditory features, the descriptions herein will focus on the external morphology for ease and practicality in field-based identifications and non-destructive lab evaluations. The external morphology of the bullae includes two main auditory chambers: the entotympanic (inner chamber) which is the prominent bulbous chamber on most of the species described, and the ectotympanic (outer chamber) which forms a canal for the auditory tube (Fig. 3). The ectotympanic can be difficult to describe because it is not prominent or inflated in some species and requires a close examination of the region to differentiate it from the entotympanic. The morphology of the auditory features differs among species (Seymour, 1999: Figs. 2-4). The general shape and development of associated processes are distinctive characters in separating mid-size felid skulls.

\section{Results}

Several features allow for distinguishing among the five species based on skull morphology (Tab. 1).

The prominence of canine grooves is an essential detail of felid canine structure and can be used as a distinguishing character among mid-sized cats (Young \& Goldman, 1946; Salles, 1992). Leopards express this character in its most obvious form (Fig. 1). Snow leopards also have prominent canine grooves. Grooves are faint to absent in the jaguar, and if present, are reduced in number, length, and depth. Canine grooves are mostly absent in the puma and cheetah, but can be faint in some specimens.

Leopards and pumas have convex nasal profiles. The expression of this character among puma subspecies was described in Wilkins et al. (1997). Snow leopards and jaguars have concave nasal profiles. The compact skull of the cheetah has a nearly straight sloping nasal profile, which is concave anteriorly (Fig. 4).

Side-to-side comparisons show the variation in size and shape of the auditory region (Fig. 5). Of the five species, jaguar, leopard, and puma have the largest auditory bullae, and the least inflated ectotympanic. 

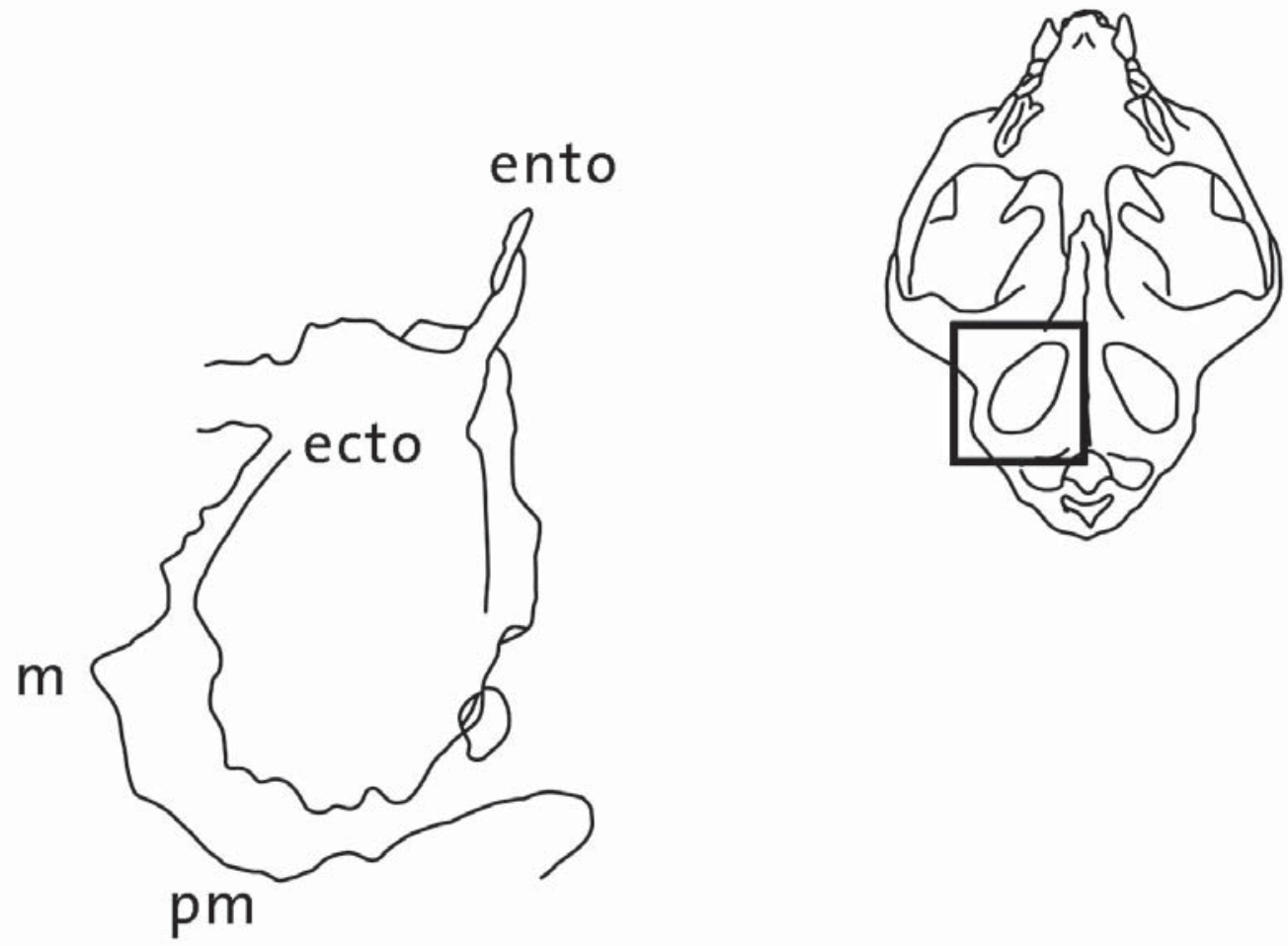

Figure 3. Auditory bulla and associated characters. Prominent bulbous shape is bulla structure. Ecto — anterior ectotympanic; ento - anterior entotympanic; $\mathrm{m}$ - mastoid; pm — paramastoid. (Adapted from Seymour, 1999).

Snow leopards and cheetahs have the most inflated ectotympanic, and the most clearly visible separation line between the two auditory chambers.

Cheetah (Acinonyx jubatus). Cheetah skulls in profile are the most domed and least elongated of the five species studied (Fig. 6). Skulls can be described as round and shortened with a broadened forehead. The highest point of the skull is above the eyes and the braincase slopes down from this point. Cheetahs have the most extreme development of frontal breadth (Salles, 1992). The infraorbital canal is small compared to similarly-sized skulls of snow leopard and puma (Fig. 7) (Ewer, 1973). The canines are reduced in size, slender, and hook backwards (Hillson, 1990). Canine

Table 1. Character descriptions among five felid species.

\begin{tabular}{|l|l|l|l|}
\hline \multicolumn{1}{|c|}{ Species } & \multicolumn{1}{|c|}{ Canines } & \multicolumn{1}{c|}{ Nasals } & \multicolumn{1}{c|}{ Auditory bullae* } \\
\hline $\begin{array}{l}\text { Cheetah } \\
\text { (Acinonyx jubatus) }\end{array}$ & $\begin{array}{l}\text { small, hooked backwards, } \\
\text { grooves absent or faint } \\
\text { concave }\end{array}$ & $\begin{array}{l}\text { straight to } \\
\text { inflated: separation line visible }\end{array}$ \\
\hline $\begin{array}{l}\text { Jaguar } \\
\text { (Panthera onca })\end{array}$ & $\begin{array}{l}\text { conical, robust, grooves } \\
\text { absent or faint }\end{array}$ & concave & $\begin{array}{l}\text { ento large, inflated with anterior } \\
\text { extension; ecto not inflated with } \\
\text { flattened projections }\end{array}$ \\
\hline $\begin{array}{l}\text { Leopard } \\
\text { (Panthera pardus })\end{array}$ & $\begin{array}{l}\text { long, more laterally } \\
\text { flattened, grooves } \\
\text { prominent often paired }\end{array}$ & convex & $\begin{array}{l}\text { ento large, inflated with minimal } \\
\text { anterior projection; ecto similar to } \\
\text { jaguar }\end{array}$ \\
\hline $\begin{array}{l}\text { Puma } \\
\text { (Puma concolor })\end{array}$ & $\begin{array}{l}\text { small, conical, grooves } \\
\text { absent or faint }\end{array}$ & convex & $\begin{array}{l}\text { ento large, inflated with minimal } \\
\text { anterior projection; ecto not inflated } \\
\text { without flattened projections }\end{array}$ \\
\hline $\begin{array}{l}\text { Snow leopard } \\
\text { (Uncia uncia })\end{array}$ & $\begin{array}{l}\text { long, more laterally } \\
\text { flattened, grooves } \\
\text { prominent }\end{array}$ & concave & $\begin{array}{l}\text { ento flattened; ecto inflated, separation } \\
\text { line visible }\end{array}$ \\
\hline
\end{tabular}

*ento - entotympanic, ecto - ectotympanic. 

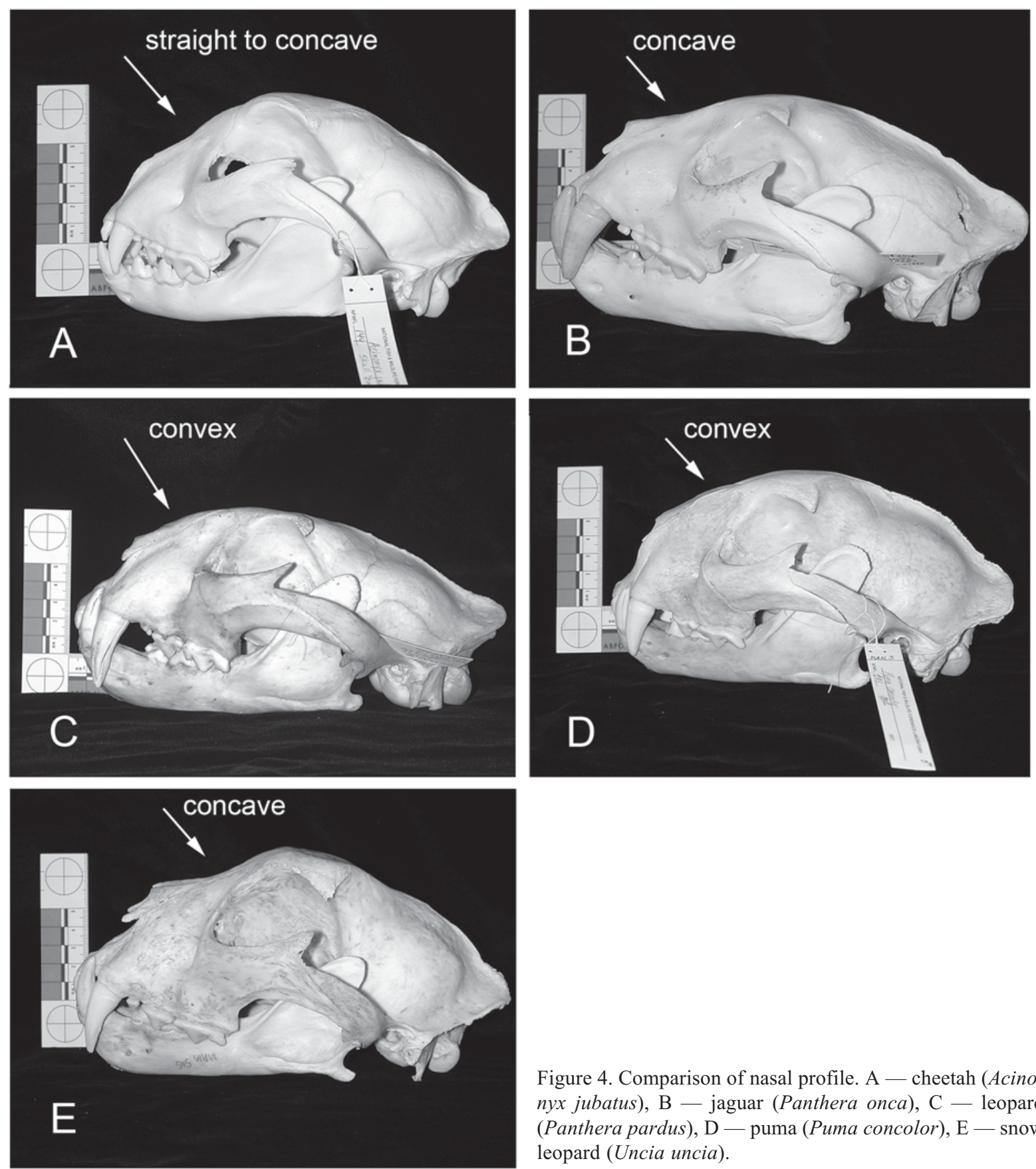

Figure 4. Comparison of nasal profile. A - cheetah (Acinonyx jubatus), B - jaguar (Panthera onca), C - leopard (Panthera pardus), D - puma (Puma concolor), E - snow leopard (Uncia uncia).

grooves are absent in most skulls but faint in some. The cheetah's nasal profile is straight to slightly concave (toward tip of nasals). The auditory bullae of the cheetah can be described as small and compact, but tall in profile with both entotympanic and ectotympanic chambers inflated. The separation line between the two chambers is visible. The styliform process of the entotympanic is a distinctive projection which extends anteriorly (toward the nasal cavity) at least one centimeter (approximately half the length of the bulla itself).
Jaguar (Panthera onca). Jaguars have the largest skulls of the five species studied here. Although skull lengths overlap with larger pantherines (e.g., tiger and lion), jaguars lack key diagnostic features found in the two biggest cats (i.e., more laterally-flattened canines and robust cheek-teeth). Jaguar skulls are robust, relatively short with a broadened rostrum and wide zygomatic arches (Fig. 8). Their robust conical canines were described as functionally significant in their prey choices, which include armored reptiles (Emmons, 1987). 

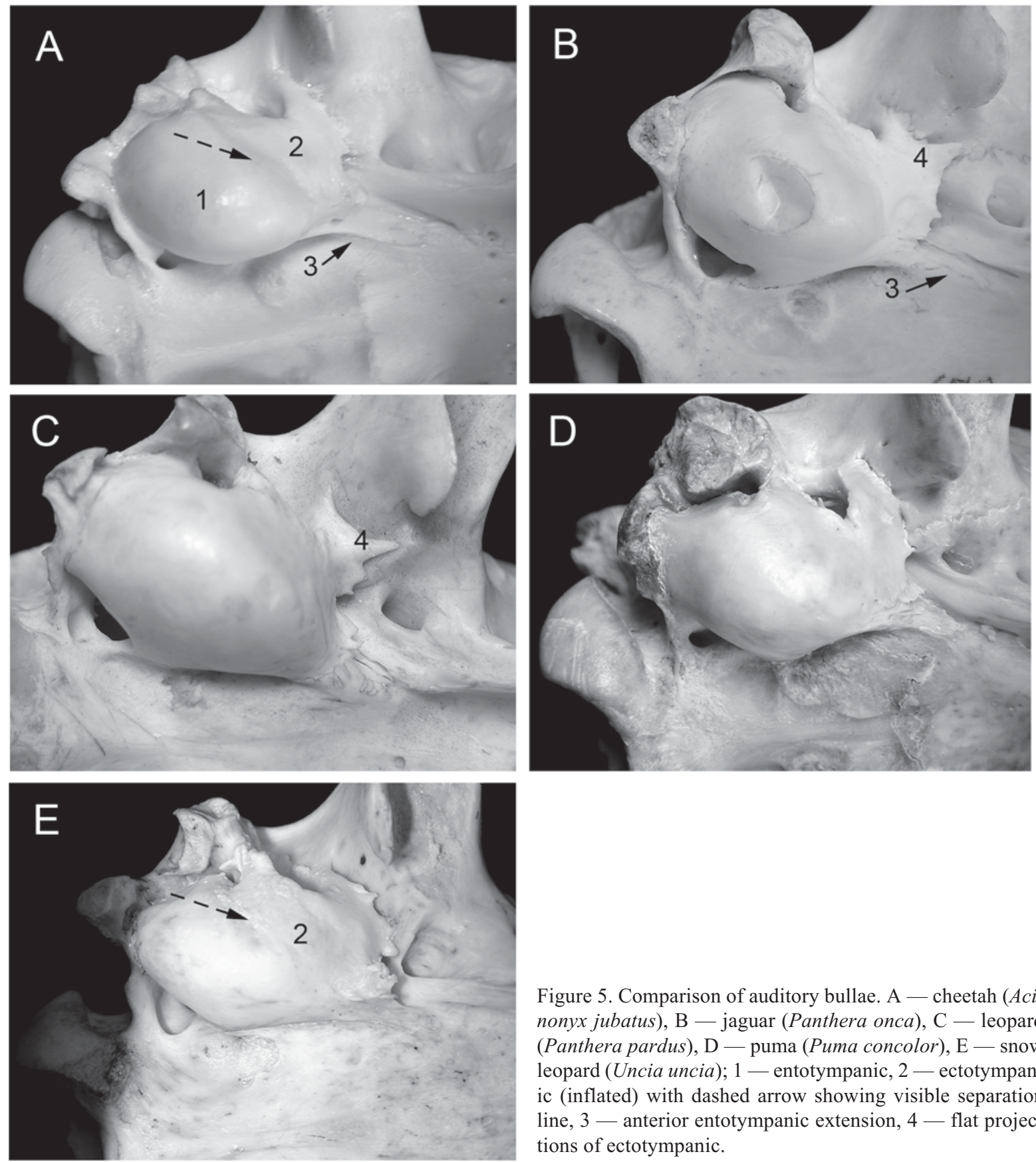

Figure 5. Comparison of auditory bullae. A - cheetah (Acinonyx jubatus), B - jaguar (Panthera onca), C - leopard (Panthera pardus), D - puma (Puma concolor), E - snow leopard (Uncia uncia); 1 - entotympanic, 2 - ectotympanic (inflated) with dashed arrow showing visible separation line, 3 - anterior entotympanic extension, 4 - flat projections of ectotympanic.

The canines rarely have prominent grooves present, but when present they are often weak or shortened along their length. Like leopards, they have a prominent canine root structure that swells toward the nasal bones (see Fig. 8A). The auditory bullae of jaguar are large, and the more prominent entotympanic is inflated. The styliform process of the entotympanic extends anteriorly (as compared to puma) (Seymour, 1999: Figs. 2-4). The ectotympanic is not inflated (as compared to cheetah and snow leopard) and forms well-developed flattened projections similar to leopard.
Leopard (Panthera pardus). The leopard skull can be described as slim and elongated (Fig. 9). Canines are elongate, slim and more laterally-flattened, often having paired parallel grooves on both lingual and labial sides of their upper and lower canines. Like jaguars, they also have a prominent canine root structure that is swollen and extends towards the nasal bones (see Fig. 9A). The entotympanic of the auditory bullae is large and inflated. The styliform process of the entotympanic does not significantly extend anteriorly (as in cheetah and jaguar). The ectotympanic is not inflated and forms flat projections similar to the jaguar. 

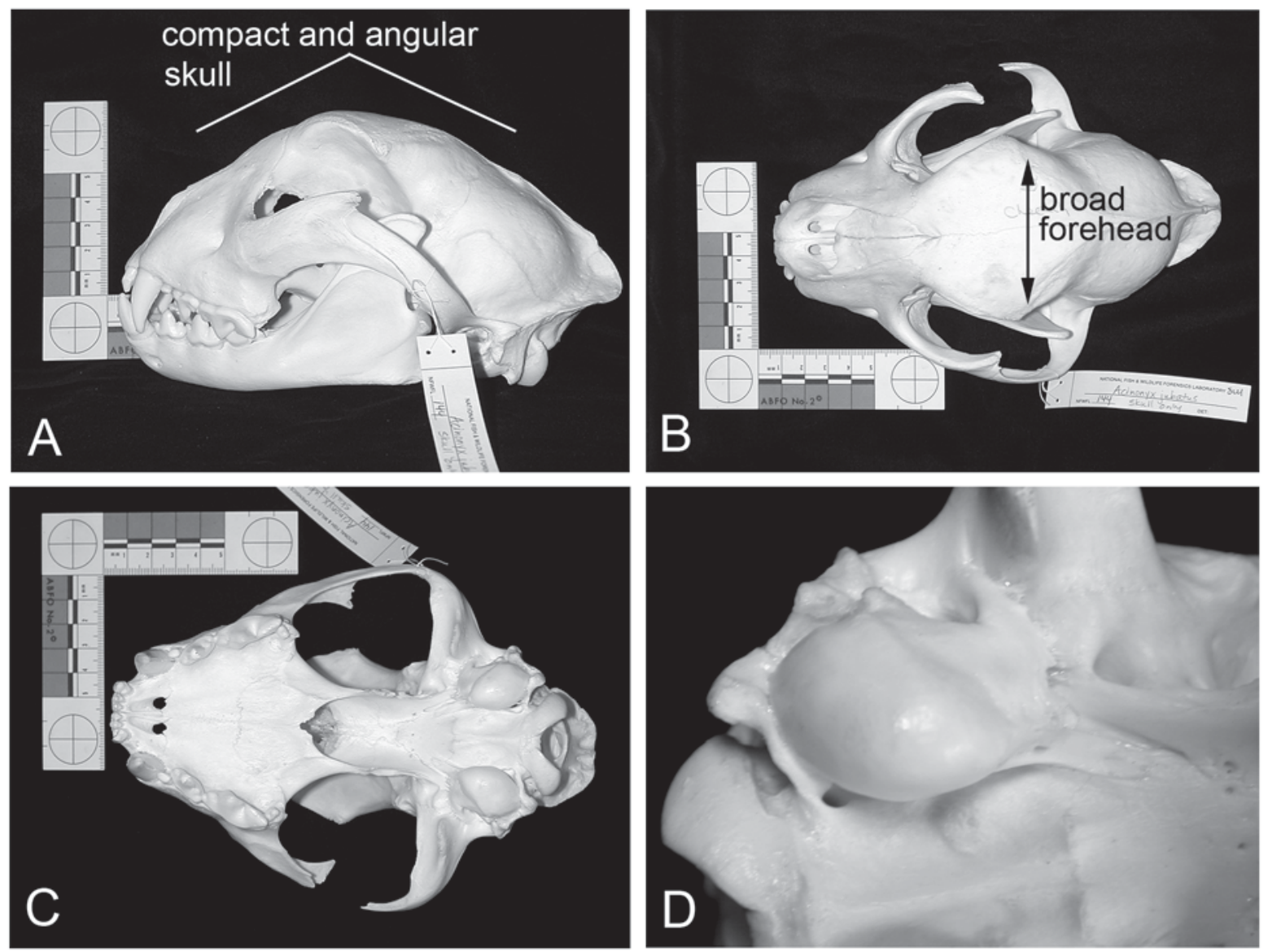

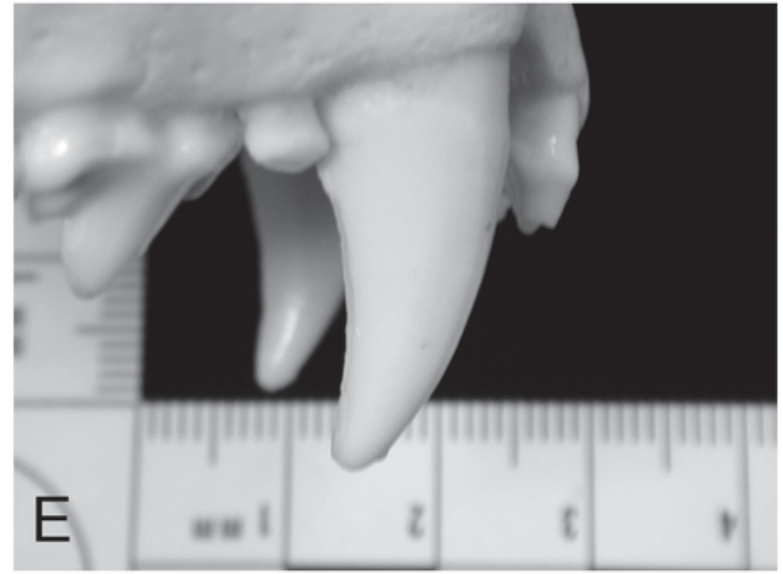

Puma (Puma concolor). Skulls of the puma are short, rounded, and compact (Fig. 10). The sagittal crest is not as prominent as in other large felids, but can be well-developed in males (Young \& Goldman, 1946). The presence of zygomatic struts was noticed along the medial surface of the temporal bone (facing the orbit) of the zygomatic arch, and was well-developed on most specimens (see Fig. 10F). These structural ridges are probably for muscle attachments for the large jaw muscles and may contribute to the limited backward-forward motion of the jaw (Young \& Goldman, 1946). Seymour (1999) describes the bregmatic process on the skull of adult pumas as well developed, which was supported in skull comparisons of NFWFL specimens. The canines of pumas are short and conical with no canine grooves (faint in a few specimens). The auditory bulla of pumas is relatively large and the prominent entotympanic chamber is inflated. The styliform process of the entotympanic does not significantly extend anteriorly as in the jaguar (Fig. 8). The ectotympanic chamber is not inflated and does not have the developed flat projections of the jaguar and leopard.

Snow leopard (Uncia uncia). The skull of the snow leopard is short and broad has been described as 

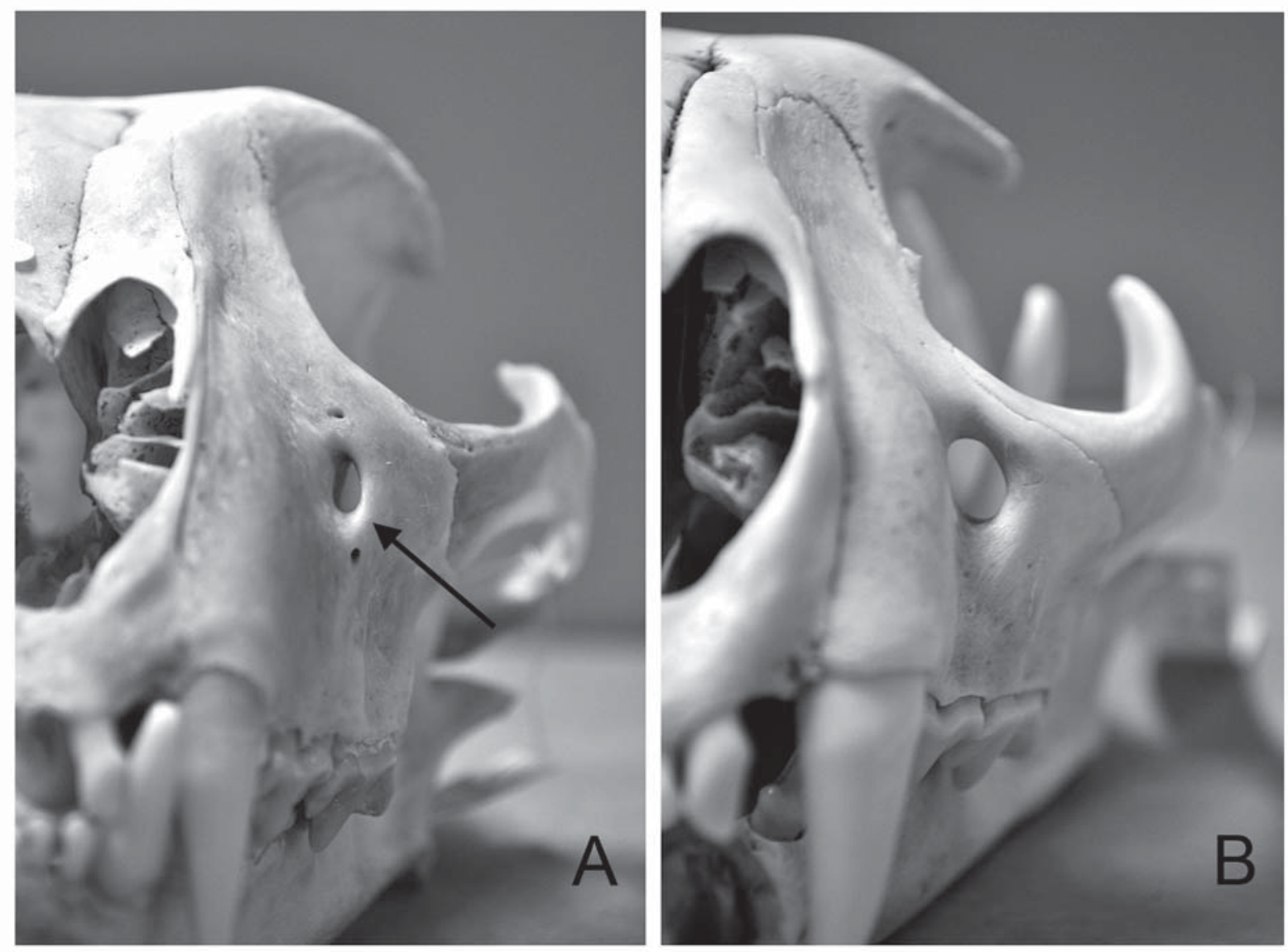

Figure 7. Comparison of infraorbital canal. A - cheetah (Acinonyx jubatus), small infraorbital canal, B — puma (Puma concolor).

highly vaulted with a broadened forehead (Fig. 11) (Hemmer, 1972). This morphology supports an enlarged nasal cavity that is an adaptation to cold climates (Haltenorth, 1937, cited after Hemmer, 1972). The broad forehead differs from that of cheetah by the presence of an outer surface depression on the frontal bone, a unique feature for Uncia (Salles, 1992). The upper and lower canines are slender, more laterallyflattened and exhibit canine grooves, with most specimens having one or two on the labial and lingual surfaces. Uncia differs from the other four species in bulla configuration. The auditory bulla is flatter (lower profile) in overall appearance than any of the other species discussed. This appearance is due to a less inflated entotympanic, and a more inflated ectotympanic. In fact, the ectotympanic approaches the size of the entotympanic. The styliform process of the entotympanic extends anteriorly, but is not prominent as in the cheetah.

\section{Wildlife law enforcement tools}

I developed a flowchart to describe the stepwise process of a preliminary morphological identification of the five species described for field investigations and laboratory use (Fig. 12). The flowchart must be used in combination with the notes presented in the text above or with the Identification Guidelines described below. As the first step in the process of using the flowchart, the canines are examined for the presence of prominent pitted grooves. Next, the nasal profile is examined to determine whether the profile is concave or convex. As a final step the auditory region is examined to support preliminary species identification.

An identification aid to illustrate the key differences to field law enforcement agents is published on the web by the NFWFL as one of a series entitled Identification Guides (Sims, 2005).

\section{Discussion}

Comparative analysis of felid cranial features enables wildlife forensic scientists to determine species identification, and ultimately to assist law enforcement investigators in the effective prosecution of cases involving violation of laws protecting these species. By a close examination of a collection of felid skulls, I reported several qualitative (non-metric) morphological features sufficient to differentiate the five species including pitted canine grooves, nasal profile, and the morphology of the entotympanic and ectotympanic pro- 

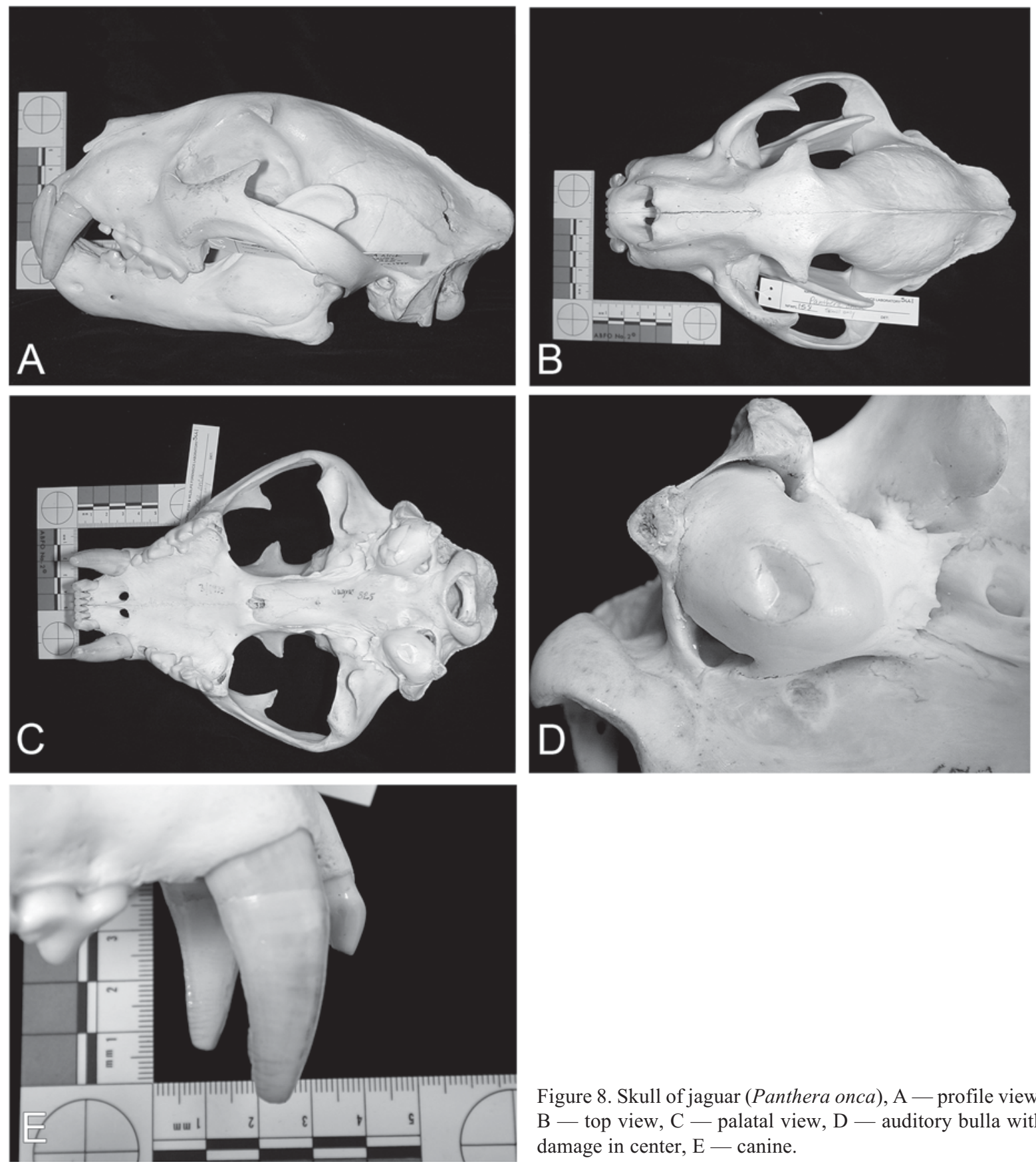

Figure 8. Skull of jaguar (Panthera onca), A - profile view, $\mathrm{B}$ - top view, $\mathrm{C}$ - palatal view, D - auditory bulla with damage in center, $\mathrm{E}$ - canine.

cesses of the auditory region. Future metric methodology might include morphotype frequency and age variation in canine grooves, and Fisher's discriminant functions.

Closely related species (especially felids) often lack single diagnostic characters which definitively discriminate among species (Garcia-Perea, 1994). A combination of characters must be used in comparative analysis. Appropriately, functional anatomy and evolutionary studies of skulls include metric approaches (Christiansen, 2005; Sicuro et al., 2011.) Morphological analysis using qualitative characters seen with the naked eye is

more easily applied when wildlife law enforcement agents and other field investigators might lack the resources to perform a sophisticated metric analysis.

Wildlife law enforcement implications

Because felids are distributed worldwide and some species may be sympatric (e.g., leopard and snow leopard), even provenance data may not be enough for a definitive identification of a medium-sized cat skull. When wildlife inspection officers examine imported skulls with questionable locality information from accompanying paperwork, the identification tools provid- 

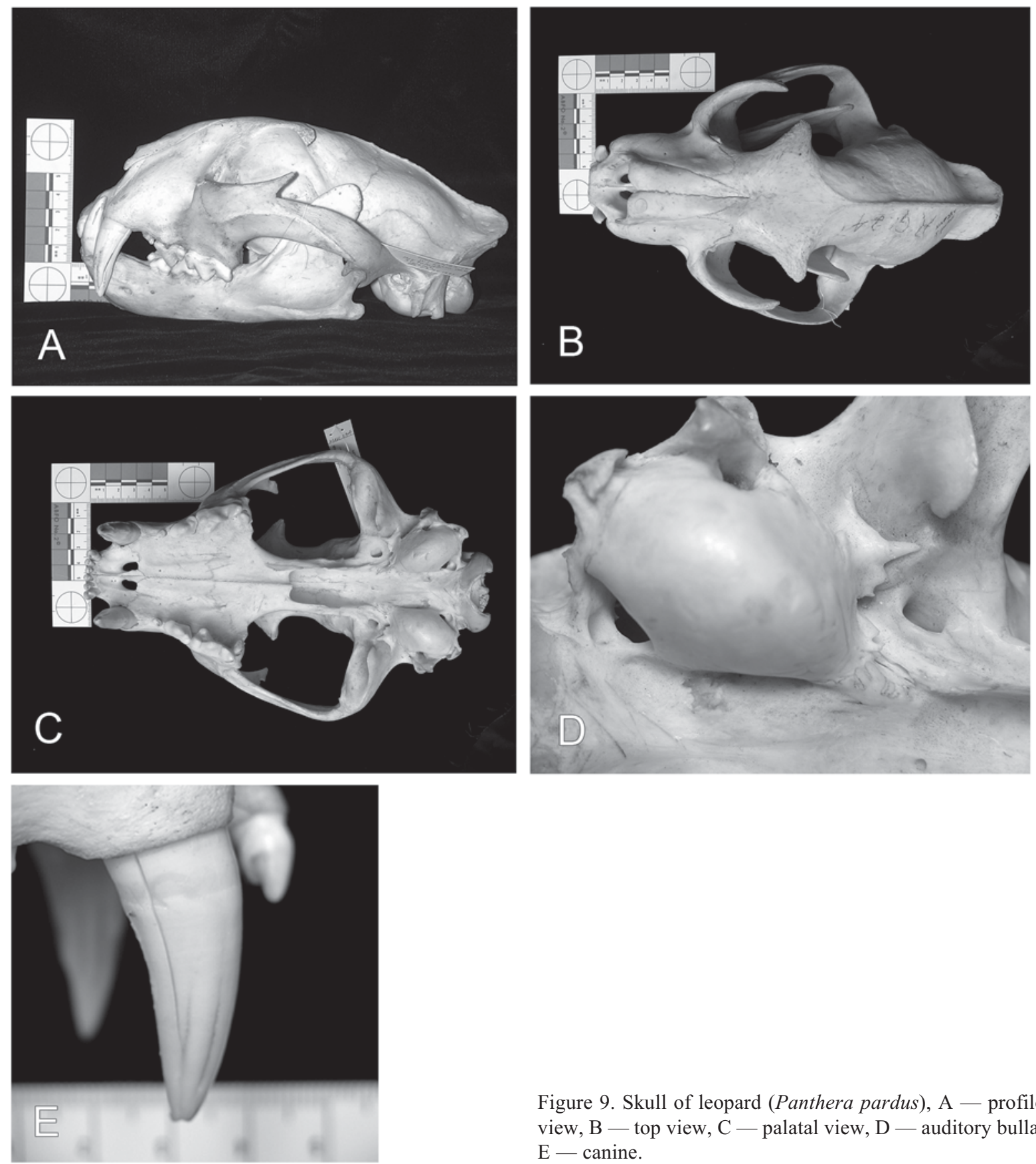

ed from this study can help field investigators establish probable cause for seizure and process shipments more efficiently.

Hundreds of felid trophies and skins are exported from countries around the world each year, legally and illegally. Wildlife inspectors in the United States process more than 116,000 wildlife shipments a year. With relatively few inspectors at 32 U.S. ports and border crossings (CITES, 2004), the trade in wildlife parts presents a challenge to control and monitor. With estimates of fewer than five percent of US import and export shipments being physically inspected (Robbins,

Figure 9. Skull of leopard (Panthera pardus), A - profile view, B - top view, C - palatal view, D - auditory bulla, $\mathrm{E}$ - canine.

1997), increased chances of smuggling are also an issue. In effect, the laws protecting wildlife are pushed to the limits of enforcement ability.

By assisting field investigators through developing research efforts, the wildlife forensics community provides expertise for effective investigations. Identification of protected species, especially from partial remains, can be impossible without comparative morphological research.

ACKNOWLEDGMENTS. The author wishes to acknowledge Bonnie Yates, Darby Morrell, Barry Bak- 

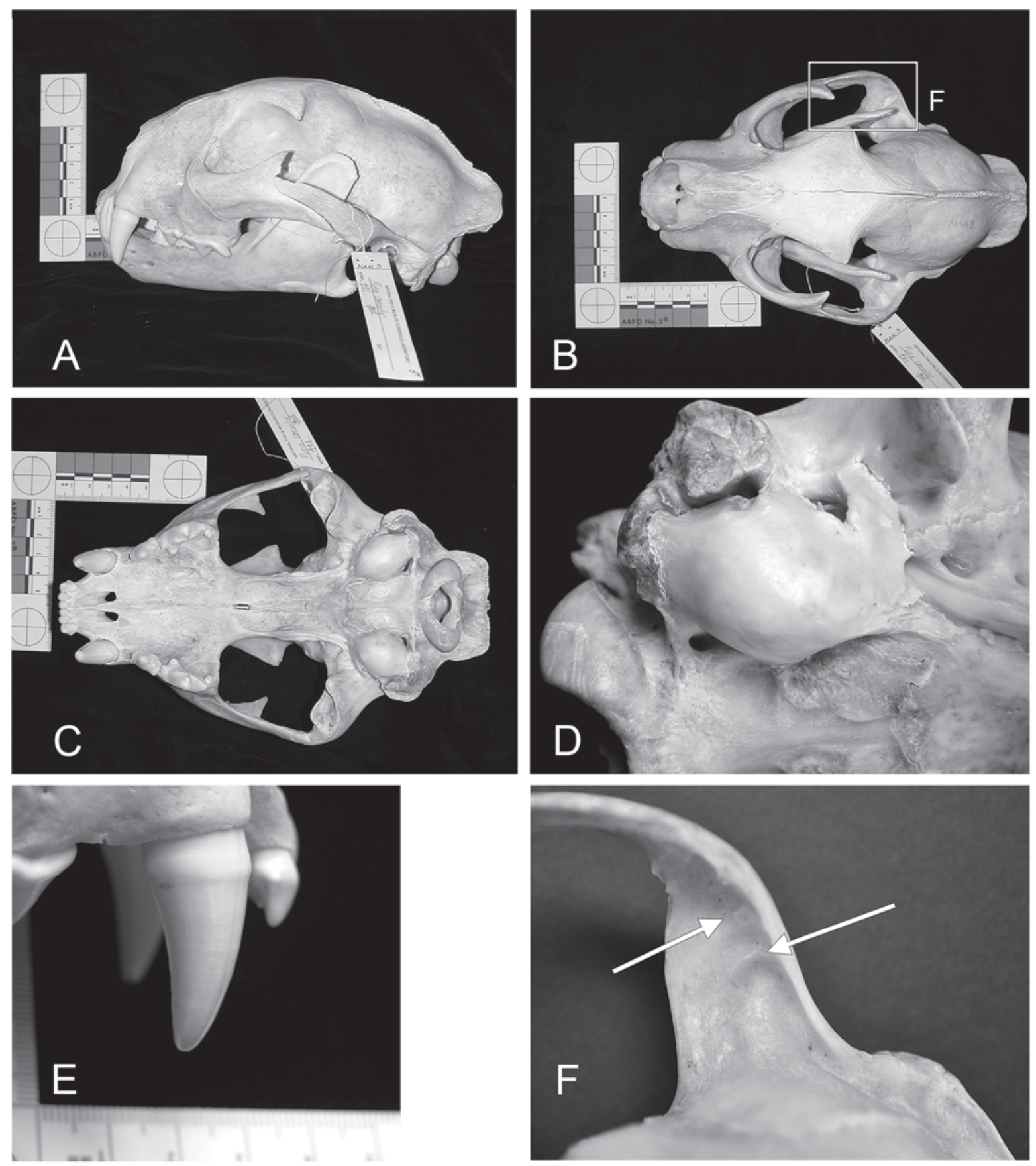

Figure 10. Skull of puma (Puma concolor), A - profile view, B - top view, C - palatal view, D - auditory bulla, E canine, $\mathrm{F}$ - detail showing structural ridges on zygomatic.

er, and Pepper Trail at the National Fish and Wildlife Forensics Laboratory for their assistance and encouragement. Suggestions and work by manuscript reviewers was invaluable and informative.Thanks to Ed Espinoza, Nat Seavy, and Kevin Seymour. An acknowledgment to collections staff at California Academy of Sciences, Field Museum of Natural History, Smithso- nian National Museum of Natural History, National Fish and Wildlife Forensics Laboratory, and the Transvaal Museum for access to specimens for data collection purposes. The findings and conclusions in this article are those of the author(s) and do not necessarily represent the views of the U.S. Fish and Wildlife Service. 

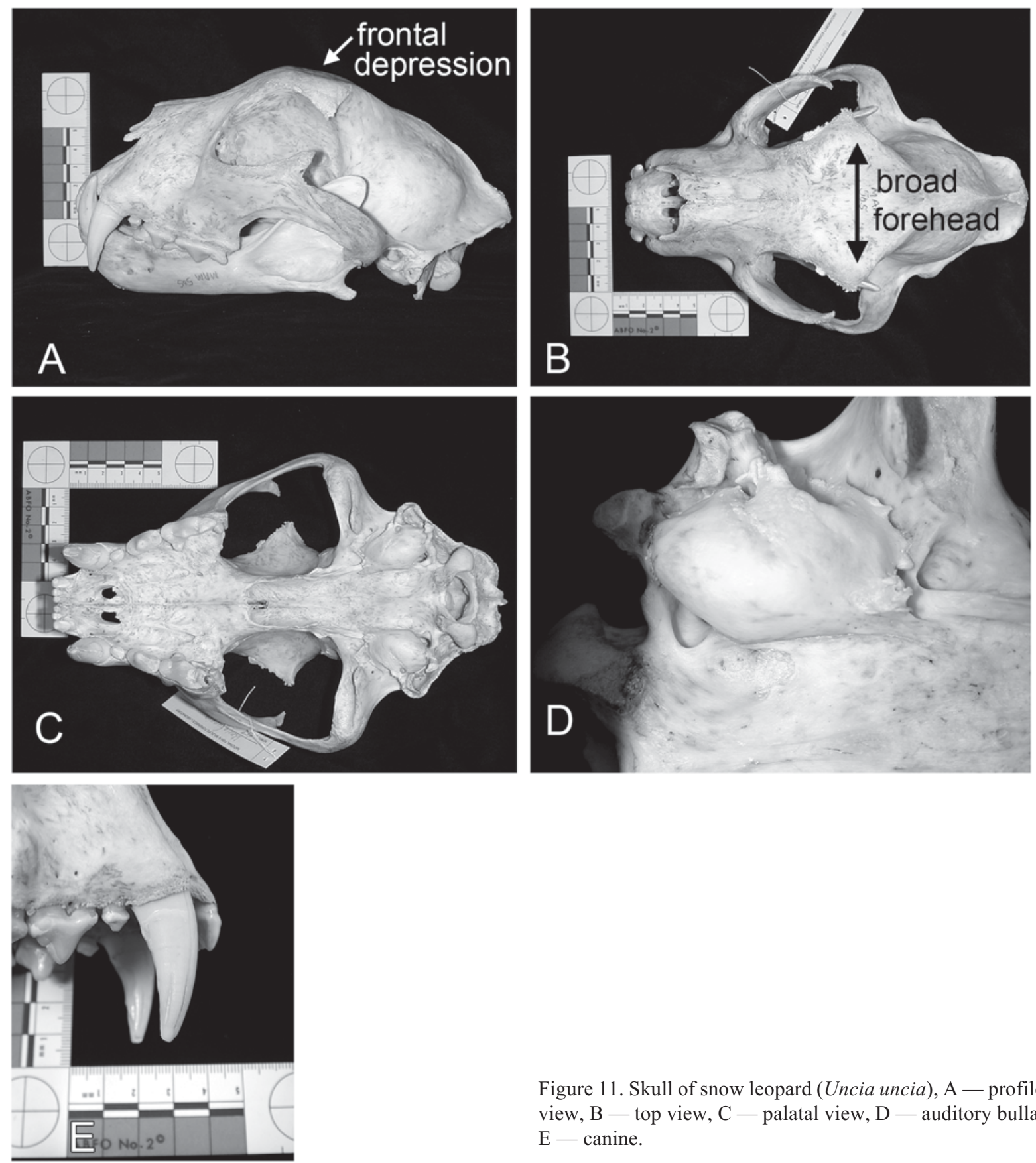

Figure 11. Skull of snow leopard (Uncia uncia), A - profile view, B - top view, C - palatal view, D - auditory bulla, $\mathrm{E}$ - canine.

\section{References}

Christiansen P. \& Adolfssen J.S. 2005. Bite forces, canine strength and skull allometry in carnivores (Mammalia, Carnivora) // Journal of Zoology (London). Vol.266. P.133-151.

CITES. 2004. Convention on International Trade in Endangered Species of Wild Fauna and Flora. 2004, March 22. Report of CITES activities by the United States since the $46^{\text {th }}$ meeting of the standing committee. $<\mathrm{http}$ ://www.cites. org/common/cttee/standing/49/esf49 24 5a.doc $>$. Accessed 2004 March 28.

Currier M. 1983. Felis concolor // Mammalian Species. No.200. P.1-7.

De Oliveira T.G. 1998a. Leopardus wiedii // Mammalian Species. No.579. P.1-6.

De Oliveira T.G. 1998b. Herpailurus yagouaroundi // Mammalian Species. No.578. P.1-6.

Emmons L.H. 1987. Comparative feeding ecology of felids in a neotropical rainforest // Behavioral Ecology and Sociobiology. Vol.20. P.271-283.

Ewer R.F. 1973. The Carnivores. New York: Cornell University Press. 484 p. 


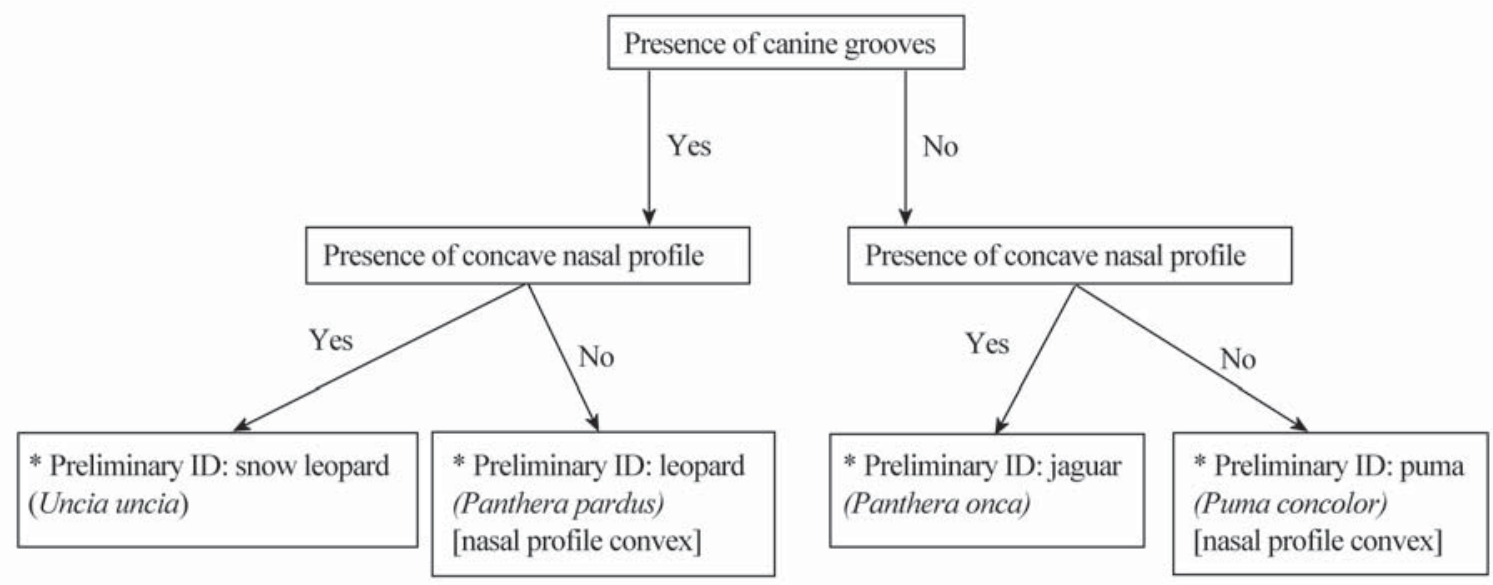

* Confirm the identification with examination of the auditory bullae characteristics mentioned in the text.

Figure 12. Flowchart with steps for preliminary identification of mid-sized cat skulls.

Garcia-Perea R. 1994. The pampas cat group (Genus Lynchailurus Severtzov, 1858) (Carnivora: Felidae), a systematic and biogeographic review // American Museum Novitates. No.3096. P.1-35.

Garcia-Perea R. 2002. Andean mountain cat, Oreailurus jacobita: Morphological description and comparison with other felines from the Altiplano // Journal of Mammalogy. Vol.83. No.1. P.110-124.

Hemmer H. 1972. Uncia uncia // Mammalian Species. No.20. P.1-5.

Hillson S. 1990. Teeth. Cambridge: Cambridge University Press. 376 p.

Holliday J. 2007. Phylogeny and Character Change in the Feloid Carnivora. PhD Dissertation. Florida State University College of Arts and Sciences.

Hunter L. 2011. Carnivores of the World. Princeton: Princeton University Press. 240 pp.

Lamerichs G. 1985. Morfologische studie van de hoektanden bij katachtigen. Dissertation, s.n. Zoölogisch instituut. Leuven: University of Leuven, Belgium. 117 p.

Lariviere S. \& Walton L.R. 1997. Lynx rufus // Mammalian Species. No.563. P.1-8.

Larsen S.E. 1997. Taxonomic re-evaluation of the jaguar // Zoo Biology. Vol.16. P.107-120.

Lekagul B. \& McNeely J.A. 1988. Mammals of Thailand. Bangkok: Association for the Conservation of Wildlife, Saha Karn Bhaet Co. 758 p.

Merriam J.C. \& Stock C. 1932. The Felidae of Rancho la Brea. Washington DC: Carnegie Institute of Washington Publication. No.422. P.1-232.

Murray J.L. \& Gardner G.L.1997. Leopardus pardalis // Mammalian Species. No.548. P.1-10.

Nelson E.W. \& Goldman E.A. 1933. Revision of the jaguars // Journal of Mammalogy. Vol.14. P.221-240.

Pocock R.I. 1916. The structure of auditory bulla in existing species of Felidae // Annals and Magazine of Natural History. Ser.8. Vol.28. P.326-334.
Robbins C. 1997. Wildlife and plant trade and the role of CITES: challenges for the $21^{\text {st }}$ century // Vance N.C. \& Thomas J. (eds.). Special Forest Products: Biodiversity Meets the Marketplace. General Technical Report WOGTR-63. Washington, DC: U.S. Department of Agriculture, Forest Service. P.146-158.

Salles L.O. 1992. Felid phylogenetics: extant taxa and skull morphology (Felidae, Aeluroidea) // American Museum Novitates. No.3047. 67 p.

Schmid E. 1940. Variations-statisische Untersuchungen am Gebiss pleistozäner und rezenter Leoparden und anderer Feliden // Zeitschrift für Säugetierkunde. Bd.15. P.1-179.

Seymour K. 1989. Panthera onca // Mammalian Species. No.340. P.1-9.

Seymour K. 1993. Size change in North American Quaternary jaguars // Martin R.A. \& Barnosky A.D. (eds.). Morphological Change in Quaternary Mammals of North America. Cambridge: Cambridge University Press. P.343-371.

Seymour K. 1999. Taxonomy, Morphology, Paleontology and Phylogeny of the South American Small Cats (Mammalia: Felidae). PhD Dissertation. Toronto: University of Toronto. 929 p. Available from: UMI Dissertation Services, Ann Arbor, MI.

Sicuro F.L. \& Oliveira L.F.B. 2011. Skull morphology and functionality of extant Felidae (Mammalia: Carnivora): a phylogenetic and evolutionary perspective // Zoological Journal of the Linnean Society. Vol.161. P.414-462.

Sims M.E. 2005. Identification of Mid-size Cat Skulls. Identification Guides for Wildlife Law Enforcement No. 7. USFWS, National Fish and Wildlife Forensics Laboratory, Ashland, OR // http://www.lab.fws.gov/idnotes/IDG7_ CatSkulls.pdf.

Todd N.B. 1966. Metrical and non-metrical variation in the skulls of Gir lions // Journal of the Bombay Natural History Society. Vol.62. No.3. P.1-14.

Tumlison R. 1987. Felis lynx// Mammalian Species. No.269. P.1-8. 
Von Den Driesch A. 1976. A Guide to the Measurement of Animal Bones from Archaeological Sites. Cambridge: Peabody Museum of Archaeology and Ethnology, Harvard University. $136 \mathrm{p}$.

Werdelin L. 1983. Morphological patterns in the skulls of cats // Biological Journal of the Linnean Society. Vol.19. P.375-391.

Werdelin L. 1985. Small Pleistocene felines of North America // Journal of Vertebrate Paleontology. Vol.5. No.3. P.194-210
Wilkins L., Arias-Reveron J.M., Stith B., Roelke M.E. \& Belden R.C. 1997. The Florida panther Puma concolor coryi: a morphological investigation of the subspecies with a comparison to other North and South American cougars // Bulletin of the Florida Museum of Natural History. Vol.40. No.3. P.221-269.

Young S. \& Goldman E.A. 1946. The Puma: Mysterious American Cat. Toronto: General Publishing Company. $358 \mathrm{p}$. 